\title{
Date seed extract diminished apoptosis event in human colorectal carcinoma cell line
}

\begin{abstract}
Apoptosis, or programmed cell death, is an essential process to remove the damaged or abnormal cancerous cells. Therefore, the study of apoptosis-inducing agents helps identifying new drugs for cancer therapy. The aim of this study was to evaluate the apoptotic effect of methanolic extract of date seed in human colon cancer cell. HT29 cells were cultured and exposed to different concentrations of date seed extract (100, 200 and $400 \mu \mathrm{g} / \mathrm{ml}$ ). Neutral comet assay was used and the patterns were classified into four groups based on the tail length and head size. Results showed that the extract has not been able to induce apoptosis in HT29 cells. Amazingly, the rate of apoptosis observed in the HT29 cells exposed to the extract, was lower than the negative control group that received no treatment. While the methanolic extract of date seed did not induce apoptosis in colon tumor cells its supporting effect on HT29 cells survival may fuels more investigation.
\end{abstract}

Volume I Issue 4 - 2015

\author{
Mohsen Rezaei,' Forouzan Khodaei, ${ }^{2}$ Neda \\ Hooshmand ${ }^{2}$ \\ 'Department of Toxicology, Tarbiat Modares University, Iran \\ ${ }^{2}$ Department of Pharmacology and Toxicology, Jundishapur \\ University of Medical Sciences, Iran
}

Correspondence: Mohsen Rezaei, Department of Toxicology, Tarbiat Modares University, Iran, Tel +98 916725 0548, Fax +98 61 33738380,Email Rezaei.mohsen@gmail.com

Received: August 24, 2015 | Published: September 15, 2015

Keywords: apoptosis, neutral comet assay, date seed, ht29

\section{Introduction}

Cancer in the last 20 years has become one of the leading causes of human deaths ${ }^{1}$ and the highest prevalence is for prostate, breast, lung, colon and rectum. ${ }^{2,3}$ Colon cancer is the second lethal cancer in both sexes in the United States ${ }^{4}$ under circumstances where normal cells change their characteristics, their growth rate become out of control, expand without interruption and disturbing the normal structure and function of tissues and organs. ${ }^{5}$ Mutagenic materials, high-fat diet, some viral and bacterial infections and ionic radiation as well as oxidative stress are among the most well-known cancer inducing factors. ${ }^{6-10}$

Epidemiological studies on cancer confirmed the presence of cancer-preventive compounds in the diet. A regular intake of fruits and vegetables reported to be associated with reduced risk of lung cancer and gastrointestinal tract. These cancer protective effects may relate to the various compounds in fruits and vegetables. ${ }^{11}$ Study on the influence of nutrition on cancer showed that the diet of rich red meat and fiber-free increases the risk of colon cancer while people who often use the fish meat are at lower risk. ${ }^{12}$ Date seed contains selenium, magnesium, potassium, calcium, phosphorus, and significant amounts of dietary fiber, lignin, and fatty acids. Also, date seeds are rich in protein, fat, dietary fiber, antioxidants, and phenolic compounds. ${ }^{13}$ Studies revealed its anti-aging, ${ }^{14}$ anti-oxidants ${ }^{15}$ and liver cell protection effects. ${ }^{16,17}$

In the present study, the effect of methanolic extract of date seed in terms of induction of the cell death (apoptosis) in human colon cancer cells was evaluated. Apoptosis induction in cancer cells is one of the most important mechanisms uses in chemotherapy. ${ }^{18}$ This is because among the two main mechanisms of cell death (apoptosis and necrosis), necrosis is a pathological cell death that along with, swelling of the cell, membrane rupture and release of the contents of cell occur. Inflammatory reactions and damage of adjacent cells would occur afterward. Apoptosis is a programmed physiological cell death that in a normal condition causes the elimination of damaged cells. With the activation of the apoptotic pathways, molecular and morphological processes like DNA fragmentation and apoptotic bodies' formation occur that eventually swallowed by macrophages. Apoptosis can kill a cell without any inflammatory impact on adjacent cells. ${ }^{19}$

\section{Materials and methods}

Cell culture materials including Dulbecco's Modified Eagle Medium (DMEM) were obtained from Applichem (Germany); penicillin-streptomycin, trypsin, and fetal bovine serum were obtained from Gibco (USA); dimethyl sulfoxide (DMSO), PBS and all comet reagents were obtained from Sigma Chemicals (Darmstadt, Germany); HT29 cell line were obtained from Pasture Institute (Tehran, Iran); Date fruit (Phoenix dactylifera L. var. dayri) collected from its natural habitat (Abadan) and identified by the local department of Pharmacognosy.

\section{Preparation of methanolic extract}

Fruit seeds were isolated and milled. Powdered seeds $(100 \mathrm{~g})$ were macerated by $1500 \mathrm{~mL}$ of $70 \%$ ethanol (v/v) for 48 hours. The extract was then shaken and filtered and the solvent was partially removed in a vacuum evaporator so that the final volume reduced to one-third of its first volume. Then the concentrated extract was freeze-dried and kept in cool and dry place until testing.

\section{Treatment}

HT29 cells $\left(10^{6}\right.$ cells $\left./ \mathrm{mL}\right)$ were exposed to different concentrations of date seed extract $(100,200$ and $400 \mu \mathrm{g} / \mathrm{ml})$ for 24 and 48 hours in 6 -well plates. As a positive control, cells were treated with anisomycin $(2 \mu \mathrm{g} / \mathrm{mL})$ for 2 hours.

\section{Comet assay}

DNA fragmentation associated with apoptosis was detected by the neutral comet assay method. HT29 cells, at a concentration of $10^{5} \mathrm{cell} \mathrm{s} / \mathrm{mL}$, were mixed with $1 \%$ low temperature melting agarose (LMPA) in PBS (Phosphate buffered saline) at a ratio of 1:10 (v/v). $100 \mu \mathrm{L}$ of cell suspension pre-mixed with low melting point agarose (LMA $1 \%$ ) poured on a slide coated with normal melting point agarose (NMA 1\%) and covered with cover slips. Slides were kept for 15 to 20 minutes horizontally in the ice tray to solidify. Next, the 
cover slips were removed from the slides and placed in a lysis solution (14.61g NaCl, 3.72g EDTA, $0.125 \mathrm{~g}$ Tris $, 0.9 \mathrm{~g} \mathrm{NaOH}, 1 \mathrm{~g}$ sodium lauryl sarcosinate $1 \%$, DMSO $10 \%$, Triton $\mathrm{x}-1001 \%$ and $\mathrm{pH}=10$ ) for one hour and then washed by deionized water, kept for 20minutes in electrophoresis buffer $\left(\mathrm{NaOH} 12 \mathrm{~g}\right.$, EDTA $372.0 \mathrm{~g}, \mathrm{dH}_{2} \mathrm{O}$ to $1000 \mathrm{~mL}$ and $\mathrm{pH}=13$ ) and electrophoresed at $25 \mathrm{~V}$ and $300 \mathrm{~mA}$ for 20 minutes and then washed with neutralized buffer (Tris $1.12 \mathrm{~g}, \mathrm{dH}_{2} \mathrm{O}$ to $250 \mathrm{~mL}$ and $\mathrm{pH}=7.5$ ) for five minutes three times. Slides were immersed in ethidium bromide solution for five minutes and analyzed by fluorescence microscope. For evaluating the comet patterns, 50 nuclei from each slide were counted and comets were scored 0-3 depending on the head size and tail length. The cells were visually scored into comet classes according to tail size class: $\mathrm{NMC}=\mathrm{No}$ migration cells (score 0 ), $\mathrm{SMC}=$ Short migration cells (score 1) $\mathrm{MMC}=$ Medium migration cells (score 2), LMC $=$ Long migration cells (score 3 ). Comets without head and those with nearly all the DNA in the tail or with a very wide tail were excluded from the evaluation, because they probably represented dead cells. Cells with the score of 0 and 1 were considered healthy while Scores 2 and 3 considered as apoptotic cells. Frequencies of the comet patterns resulting from 100, 200 and $400 \mu \mathrm{g} / \mathrm{ml}$ of methanolic extract of the date seed were calculated and compared with the positive control (anisomycin) values. ${ }^{20}$

\section{Statistical analysis}

Statistical analysis was performed using the non-parametric X2 test to compare groups of data.

\section{Results}

HT29 cells following 24 and 48hours exposure to different concentrations of date seed extract to determination of the type of cell death was evaluated by comet assay technique. Anisomycin was considered as a positive control and also negative control cells did not receive any drug. Each slide analyzed using fluorescence microscope, 50 cells were considered and comet patterns (score 0 , score 1 , score2, score3) in each group were counted. The percentage of healthy cells and apoptotic cells based on the patterns of comet and in comparison with the control groups were presented.

Figure 1 shows the frequency of comet patterns in HT29 cells exposed to anisomycin $(2 \mu \mathrm{g} / \mathrm{ml})$ and $100,200,400 \mu \mathrm{g}$ date seed extract for 24hours (Figure 1A) and 48 hours (Figure 1B). Result showed that by all extract concentrations at 24 and 48 hours apoptotic events was not observable.

Never the less at $100 \mu \mathrm{g} / \mathrm{ml}$ the frequency of comet patterns were same as a negative control group, at 200 and $400 \mu \mathrm{g}$ significant reductions in the apoptotic events were observed.

Figure 2 shows the percentage of apoptotic cells exposed for 24 hours (Figure 2A) and 48h (Figure 2B) with various concentrations of date seed extract $(10,100,200,400 \mu \mathrm{g} / \mathrm{ml})$ and positive control Anisomycin $(2 \mu \mathrm{g} / \mathrm{ml})$. Rate of apoptosis in all concentrations was significantly lower than positive control group. At 200 and $400 \mu$ g significant reduction was observed in apoptotic cell death and compared to the negative control group, by increasing the concentration, a significant reduction in the rate of apoptosis was evident. The rate of apoptosis in all concentrations was significantly less than the positive control group. Figure $2 \mathrm{C}$ shows the percentage of apoptotic cells exposed for 24 hours and 48 hours with various concentrations of date seed extract $(10,100,200,400 \mu \mathrm{g} / \mathrm{ml})$ and positive control anisomycin $(2 \mu \mathrm{g} / \mathrm{ml})$. The results showed that the rate of patterns associated with apoptosis (score 2 and 3) exposed to the date seed extract for 48 hours were less than those exposed for 24 hours. Figure 2D shows percentage of healthy cells exposed to different concentrations of date seed extract and positive control anisomycin, and again the percentage of healthy cells in all groups significantly $(\mathrm{P}<0.001)$ was higher than the cells received anisomycin.

\section{Discussion}

Because of the diverse climates, Iran is home of various valuable species of medicinal plants. Identification of therapeutic properties of these plants has attracted a lot of attention over the past two decades and a lot of researches have been done in this area.

Cancer has become one of the leading causes of human deaths ${ }^{1}$ with the higher incidences including prostate, breast, lung, colon and rectal. ${ }^{2,3}$ In the United States, approximately 148,810 new cases of colorectal cancer are diagnosed each year and approximately 49,960 of Americans die each year due to the colon cancer. ${ }^{21}$

Date fruit and its components suggested being effective against cancer. A study conducted in vitro indicated that the date fruit has an anti-neoplastic effect through the regression of sarcoma tumors. 22 Results for the date fruit extract from the Ames test indicated that the mutagenicity induced by benzo $[\alpha]$ pyrene was inhibited in the TA98 and TA-100. ${ }^{23}$ Date fruit components that may have anti-oxidant and indeed anti-mutagenic properties include proanthocyanidin, anthocyanin, beta-carotene, and phenolic acid..$^{24}$ Date seeds are also rich in phenolic compounds and proanthocyanidin. The presence of the phenolic compounds with the potential to eliminate free radicals will strengthen its anti-mutagenic effect.

Dates are rich in selenium and some studies linked its antimutagenic effects against carcinogenic substances accordingly. ${ }^{24,25}$ In a study on ten varieties of dates grown in different regions of Saudi Arabia, the presence of selenium in the date seeds were reported. ${ }^{26}$ Selenium has anti-mutagenic and anti-antioxidant effects and its effect on enzymes involved in DNA repair seems to be significant. ${ }^{27}$ Methanolic extract obtained from seeds and pulp of the date showed strong antioxidant effects in vitro. ${ }^{28}$

Antioxidant, ${ }^{28,29}$ anti-mutagens, ${ }^{23}$ anti-neoplastic ${ }^{22}$ and antiaging ${ }^{26}$ effects reported for the date fruit and given that the induction of apoptosis in cancer cells is one of the highly desired mechanism of function for cancer therapy ${ }^{30}$ directed us to examine the possible apoptotic effect of the methanolic extract of date seed in human colon cancer cells.

At the beginning, concentrations of 100,200 and $400 \mu \mathrm{g} / \mathrm{ml}$ were used and finally, we increased the concentration to 2500 and $5000 \mu \mathrm{g} /$ $\mathrm{ml}$ for 48 hours.

Through the images obtained from fluorescence microscope nucleus of apoptotic cells was in the form of a comet with a long tail and a small head. Comparison of the frequency of comet patterns exposed to anisomycin show that prevalence of comet patterns with the score 2, 3 (apoptotic cells) were significantly higher than comet pattern with the score 0,1 (normal cells) (Figure $1 \& 2$ ). Exposure to anisomycin affected about $60 \%$ of the cells toward apoptosis and the rate of apoptosis in all extract concentrations were significantly lower than positive control, that is, by increasing the concentration, a significant reduction in the rate of apoptosis was observed compared to the negative control group. Even at very high concentrations (2500 
and $5000 \mu \mathrm{g} / \mathrm{ml}$ ) for $48 \mathrm{hrs}$. Apoptotic feature was not noticeable. The absence of apoptosis features can be associated with the effects of date seed components such as selenium and flavonoids and somehow shows that these components may behave like a double-edged sword and their action is dependent on their concentration, duration of exposure and the cell type. A Study on methanol extracts of pulp and date seed, showed that the seed methanol extract totally has higher amounts of phenolic compounds, pro anthocyanidins and flavonoids. ${ }^{30}$ Flavonoids anti-inflammatory and anti-cancer properties reported to be dose dependent and selenium inhibited cell apoptosis induced by oxysterols in the vascular smooth muscle cells. ${ }^{31}$ In contrast, by activating the JNK pathway the cyto protective effect of selenium against apoptosis induced in LLC-PK1cells has been reported..$^{32}$ It is likely that date seed may have some components with opposing activity and need to be examining separately. Also, the HT29 cells may not be the appropriate sensitive cell line to exhibit cyto toxicity induced by the date seed extract.
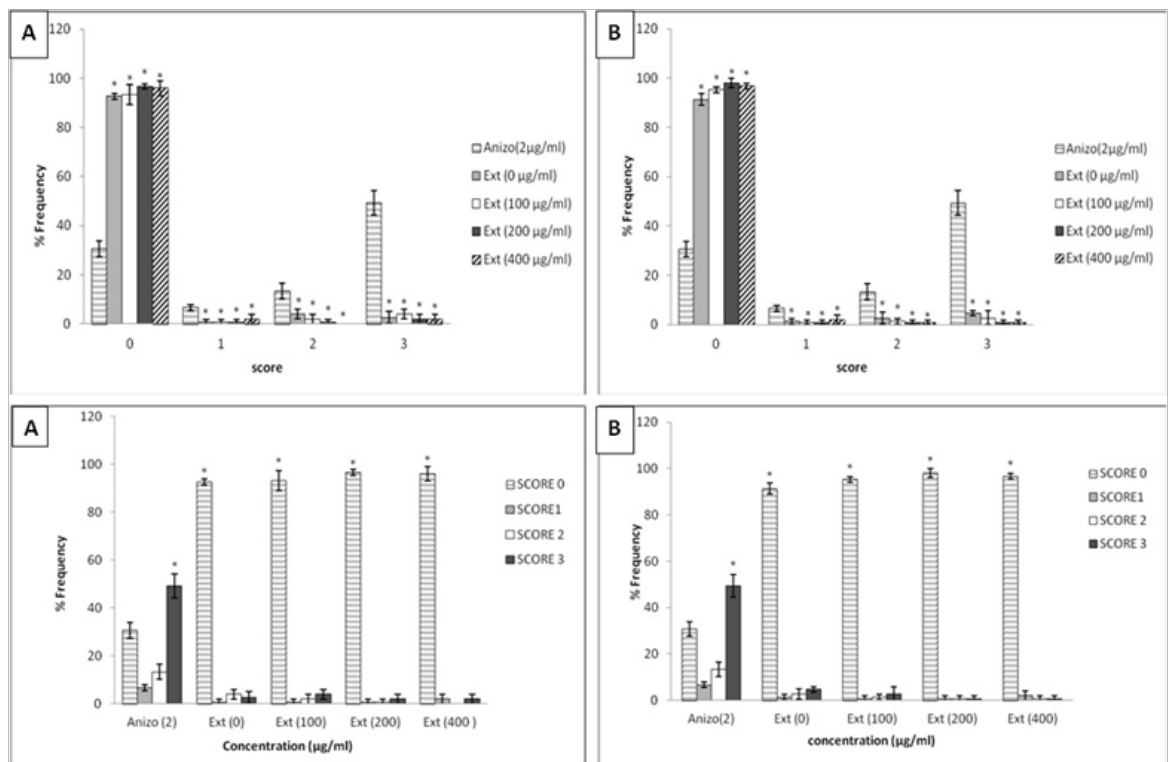

Figure I Frequency of comet patterns among HT29 cells exposed to different concentrations of date seed extract for A: 24hrs and B: 48hrs Scores were calculated and compared with the positive control (anisomycin:Anizo) values.

*Significant difference in comparison with anisomycin $(\mathrm{P}<0.00 \mathrm{I})$.
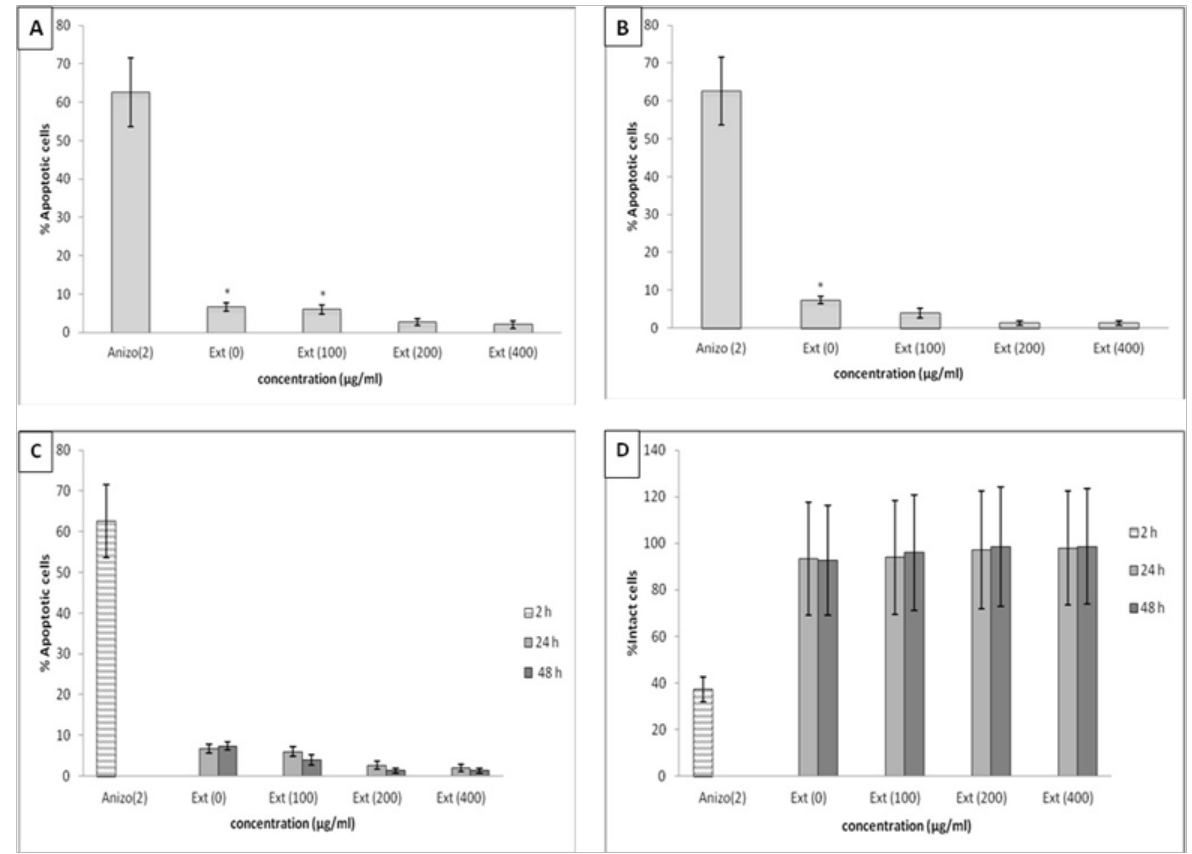

Figure 2 The percentages of apoptosis (score 2+ score 3) among HT29 cells exposed to different concentrations of date seed extract for A: 24hrs and B: 48hrs Scores were calculated and compared with the positive control (anisomycin:Anizo) values

*Significant difference in comparison with 200 and $400 \mu g / m l(P<0.05)$, apoptosis in all groups significantly $(P<0.00 \mathrm{I})$ lower than anisomycin received cells. 


\section{Acknowledgements}

This work was supported by a grant (CMRC-40) from the Jundishapur University of Medical Sciences, Ahvaz, Iran

\section{Conflict of interest}

The author declares no conflict of interest.

\section{References}

1. Longo D. Oncology and hematology. In: Harrison T, editor. EHsimtEUMHs; 2008. 5:335-337.

2. Balmer CM, Iannucci A. Cancer treatment and chemotherapy. In: Di Piro JT, Talbert RL, Yee GC, editors. Pharmacotherapy: A Pathophysiologic Approach. 6th ed. USA: Mc Graw-Hill; 2005. p. 2279-2328.

3. Blot WJ. Epidemiology of cancer. In: Goldman L, editor. Cecil Textbook of Medicine. 22nd ed. USA: WB Saunders; 2004. p. 1116-1120.

4. Stone WL. PATateoccJotNCIJ-PPE.

5. Akhoond M, Kajemnejad A, Hajizadeh E. Comparison of influential factors affecting survival of patients with colon and rectum cancer using competing risks model. Koomesh. 2010;12:119-128.

6. SRPotr-aefbcarCRFSN. 105-121.

7. Armstrong BK, Kricker A, Fleming C. sunlight and cancer. Cancer causes control. 1997;8(3):271-283.

8. Trichopoilon A, Katsouyanni K, Stuvar S. Consumption of olive oil and specific food groups in relation to breast cancer risk in Greece. J natl Inst. 1995;87(2):110-119

9. Sambanthamurthi R, Sundram K, Tan YA. Chemistry and biochemistry of palm oil. Prog lipid Res. 2000;39(6):507-558.

10. Park Y, Hunter DJ, Spiegelman D. Dietary Fiber intake and risk of colorectal cancer: a pooled analysis of prospective cohort studies. JAMA. 2005;294(22):2849-2857.

11. Jiang Q, Christen S, Shigenaga M. Gamma-tocopherol the major form of vitamin $\mathrm{E}$ in the US diet, deserves more attention. Am J Clin Nutr. 2001;74:714-722.

12. Engeset D, Andersen V, Hjartaker A, et al. Consumption of fish and risk of colon cancer in the Norwegian Women and Cancer (NOWAC) study. The British journal of nutrition. 2007;98(3):576-582.

13. RFAsarmfdoaihcNAR. 52-43.

14. Al Farsi MA LCNafpodarCRiFSaN.

15. Al Qarawi AA, Ali BH, Mousa HM, et al. Protective effect of extracts from dates (Phoenix dactylifera L.) on carbon tetrachloride-induced hepatotoxicity in rats. The International Journal of Applied Research in Veterinary Medicine. 2004;3:176-180.
16. Pollack M, Phaneuf S, Dirks A, et al. The role of apoptosis in the normal aging brain, skeletal muscle, and heart. Ann NY Acad Sci. 2002;959:93107.

17. Barbouti A, Douliyas PT, Nousis L, et al. DNA damage and apoptosis in hydrogen peroxide exposed Jurkat cells: bolus addition versus continuous generation of $\mathrm{H}_{2} \mathrm{O}_{2}$. Free Radic Biol Med. 2002;33(5):691-702.

18. Sloop GD, Rova JC, Delgado AG, et al. Histologic sectioning produces TUNEL reactivity. A potential cause of false-positive staining. Arch Pathol Lab Med. 1999;123(6):529-532.

19. Gal I, Varga T, Szilagyi I, et al. Protease-elicited TUNEL positivity of non-apoptotic fixed cells. J Histochem Cytochem. 2001;48(7):963-970.

20. Rezaei M, Khodaei F, Sayah Bargard M, et al. Long-term methadone intake and genotoxicity in addicted patients. Jundishapur J Nat Pharm Prod. 2015;10(1):e17008.

21. Calvert PM. FHMgoccAahwuccm-g-o-c-c.

22. Ishurda O JFTa-caoppfLdPdLCP.

23. VPAaapoaeodfPdLAJoAaFC. 610-617.

24. Brockman HE, Stack HF, Waters MD. Antimutagenicity profiles of some natural substances. Mutat Res. 1992;267(2):157-172.

25. Jassim SAA. NMIveotaaoaeodpPdLpoappEbca.

26. Bauza EDpkeeapasrswIJoTR.

27. Ferguson LR, Phillpot M, Karunasinghe N. Dietary cancer and prevention using antimutagens. Toxicology. 2004;198(1-3):147-159.

28. Arawande JO, Ogunyemi OY. Effect of Methanol and Water Extract of African Lettuce (Lactuca taraxacifolia) on Stability of Refined Palm Kernel Oil. Nigerian Food Journal. 2012;30(2):1-7.

29. Siahpoosh A, Gol Fakhrabadi F, Jorkesh F. Deterimiation and comparison of antioxidant activity of aqueous and methanol extracts of date palm (Phoenix dactylifera L. var dayri). Pejouhesh. 2011;35(2):81-68.

30. Hashemi M, Karami Tehrani F, Farzami B. Caspase dependent apoptosis induced by Cladribine in the estrogen receptor negative breast cancer cell line, MDA, MB468. Journal of Sciences. 2003;14(4):303-310.

31. Tang R, Liu H, Wang T, et al. Mechanism of selenium inhibition of cell apoptosis induced by oxysterols in rat vascular smooth muscle cells. Arch Bichem Biophys. 2005;441(1):16-24.

32. Liu Y, Zhang SP, Cai YQ. Cytoprotective effects of selenium on cadmium-indeced LLC-PK1 cells apoptosis by activating JNK pathway. Toxicol In Vitro. 2007;21:677-684. 